\title{
LEITURAS MEDIADAS DO CONTO NA SALA DE AULA
}

\author{
Marcos Vinícius Scheffel
}

\section{RESUMO}

No ensino médio, a literatura costuma aparecer como conhecimento enciclopédico e leitura de simulacros de obras literárias. O presente trabalho questiona tais práticas e oferece como alternativa uma abordagem em que o professor se torna mediador de leituras, direcionando seu foco de atuação para a recepção dos textos pelos alunos. Para ilustrar tal proposta, comentam-se as possibilidades didáticas do conto em sala de aula.

PALAVRAS-CHAVE: mediação de leitura; o conto na sala de aula; educação literária.

\section{A didática da não leitura}

É útil pensar a educação literária como uma aprendizagem de percursos e itinerários de tipo e valor variáveis. A tarefa da escola é mostrar as portas de acesso. A decisão de atravessá-las e em que medida depende de cada um.

Teresa Colomer

m seu livro O demônio da teoria: literatura e senso comum (2010), Antoine Compagnon destaca as perspectivas utilizadas para tratar do fenômeno literário, da Antiguidade à Pós-modernidade. Nos seis capítulos do livro, Compagnon se detém sobre: a perspectiva autoral; a relação da representação literária com o real; o leitor e o texto literário; as discussôes em torno do estilo; a visão historiográfica; e a questão do valor literário. Olhando para essas seis possibilidades de abordagem do texto literário, podemos 
assegurar que é a historiografia literária que dá as cartas na escola brasileira, principalmente, no ensino médio. As outras possibilidades estão a serviço dessa historiografia literária escolar, assim: o autor é um nome dentro de um quadro histórico, tal livro representa dada sociedade, o estilo do autor está relacionado a determinada escola literária. Já o valor das obras é justificado pela sua cobrança em exames de seleção, ou seja, pelo pertencimento a uma tradição de ensino.

O maior problema gerado por tal concepção é que nela as obras literárias não são lidas em sua integridade. Essa não leitura, na escola brasileira, é sustentada por um paradoxo: tais obras são importantes (por serem cobradas em exames), mas nossos alunos ainda não têm maturidade para realizar a leitura integral desses textos. A esse leitor é oferecida apenas uma visão panorâmica da literatura brasileira. $\mathrm{O}$ aluno passa de possível leitor a expectador passivo de uma cultura enciclopédica que pouco ou nada lhe diz. O livro didático e as apostilas sustentam essa práxis pedagógica ao fornecerem fragmentos das obras e ao prepararem para os exames, motivo maior de toda nossa educaçáo. Por sua vez, grande número de professores reitera essa prática ao pautar suas aulas somente nas lições do livro didático.

Importante frisar que o simulacro do texto ${ }^{1}$ não deve ser banido, mas deve ter seu lugar redefinido. Atualmente, ele é o substituto do texto, a única forma como os estudantes (e muitos professores) se relacionam com a literatura. Para Teresa Colomer, essas leituras de caráter valorativo devem ser trazidas a posteriori "com a intenção de aumentar a fruição da obra" (COLOMER, 2007, p.108).

A leitura de obras em sua integridade é uma prática em extinção. Muitas vezes ela acontece apenas no plano discursivo: a indicação da leitura de um livro a alunos de determinada série, que não será realizada efetivamente, pois eles aprenderam a acessar os textos que comentam o livro (resumos, roteiros de leitura, questóes cobradas em avaliaçóes). Aliás, essa prática lhes foi ensinada na escola, que substituiu o texto pelo paratexto como princípio didático. Por essa perspectiva, o valor das obras existe em um plano discursivo, mas não precisa ser vivenciado. Isso pode ser facilmente detectado

1 Entendo aqui o simulacro como tudo aquilo que substitui a leitura e discussão do texto: comentários sobre a obra, resumos, resenhas, informaçóes históricas. Trata-se de algo que parece com literatura, mas que na verdade é algo que está no lugar dela. 
conversando com as crianças e jovens que frequentam nossa educação básica. Muitos estudantes universitários também relatam que passaram por toda educação básica sem que nunca lhes fosse indicada uma única obra literária para leitura. O aluno é o turista que passeia por um museu orientado por um guia, o professor, que lhe fornece uma visão parcial da obra, um dado pitoresco, uma curiosidade. O papel desse leitor-colegial é o de alguém que deve admirar determinada obra, de determinada maneira (cf. HOUDART-MÉROT, 2013, p. 103-115).

Quando ocorre uma indicação de leitura, o gênero predominante é o romance, que potencializa a leitura de simulacros de livros. Raramente é indicada a leitura de um livro de poemas em sua integridade. ${ }^{2} \mathrm{O}$ mesmo vale para um livro de contos ou de crônicas. Esses gêneros servem para leitura rápida da sala de aula, seguida de exercício para aferir o entendimento dos textos (leitura que se limita a pedir para os alunos responderem as questóes sobre determinado texto em determinada página, sem que haja qualquer tipo de mediação). Já a preferência pelo romance se justifica, de um ponto de vista da historiografia adotada nas escolas, por ser este o gênero de consagração dos grandes autores. Grandes poetas também merecem destaque, mas pela perspectiva da publicação de poemas emblemáticos, reiterando o caráter antológico da literatura na escola.

Além dessas questóes, ligadas a uma tradição de ensino repetida de norte a sul do país, falta-nos uma discussão mais qualificada sobre as condiçoóes de leitura no Brasil e sobre os modos como os jovens leem atualmente. Nessa direção, a percepção de que cada geração estabelece um modo de se relacionar com a leitura deveria determinar a forma como as obras literárias são abordadas na escola ou pelo menos ajudar a entender o tipo de dificuldade enfrentada pelo aprendiz.

São recorrentes, por exemplo, as reclamaçóes dos professores de vários níveis de ensino sobre a dificuldade dos alunos em lerem textos longos por falta de concentração. Esse aspecto foi comentado recentemente por Zygmunt Bauman:

2 Na condição de professor de Prática de Ensino de Português e Literatura da UFRJ, das vinte aulas de regência assistidas em 2014, apenas uma teve como base a indicação de um livro de poemas: Menino do mato, de Manoel de Barros. Isso ocorreu no Colégio de Aplicação da UFRJ, com a supervisão do professor André Uzêda. 
A educação é vítima da modernidade líquida, que é um conceito meu. O pensamento está sendo influenciado pela tecnologia. Há uma crise de atenção, por exemplo. Concentrar-se e se dedicar por um longo tempo é uma questão muito importante. Somos cada vez menos capazes de fazer isso da forma correta. [...] Isso se aplica aos jovens, em grande parte. Os professores reclamam porque eles não conseguem lidar com isso. Até mesmo um artigo que você peça para próxima aula eles não conseguem ler. Buscam citaçóes, passagens, pedaços (BAUMAN, 2015, p. 41).

Ao que tudo indica, essa crise de atenção decorre do choque entre novas práticas de leitura, vivenciadas pelos alunos, com práticas de leitura ligadas ao tempo da escola. Na visão de Muniz Sodré, com a irrupção dessa nova cultura midiática "entram em crise as instituiçôes assentadas sobre a duração [como a escola], isto é, sobre o tempo ou a passagem de um antes para um depois experimentado como continuidade e coexistência” (SODRÉ, 2012, p.195). No caso da literatura, o embate é entre: a leitura de um cânone escolar que pode trazer textos e formas de leitura que estáo afastados há séculos do aluno versus as formas de interação textual vivenciadas no dia a dia por esses jovens leitores. Para citar apenas um exemplo desse embate, há um bom tempo parte significativa dos alunos têm enfrentado barreiras para ler romances da forma como isso é proposto pela escola: sem o entendimento das dificuldades de leitura e sem propostas de mediação por parte do professor.

Romances podem e devem fazer parte das indicaçóes de leitura da escola, mas isso exige outro tipo de mediaçáo. Deve-se encarar que o romance é um gênero que teve entre os séculos XVIII e XIX o seu grande momento. Ele estava afinado com um modo de vida burguês, com um tempo de leitura a ser dispendido e com temas daquele universo. Lembrando que no Brasil o gênero fixou-se apenas em meados do século XIX, com o adensamento da vida urbana e de modos de vida burgueses.

Porém, mesmo o leitor do século XIX já começava a mostrar sinais de cansaço e o desejo de leituras mais rápidas que o romance, como aquelas oferecidas pelos jornais e revistas. De olho nesse tipo de leitor, Edgar Allan Poe desenvolveu uma teoria do conto fundamentada no tempo de atenção dispendido por um leitor e nas formas de manter este leitor preso ao conto, por isso 
a necessidade de que não houvesse detalhes inúteis e que todos os elementos confluíssem para o final. O tempo de atenção do leitor contemporâneo não é obviamente o mesmo daquele leitor imaginado por Poe. No entanto, este tempo se aproxima do tempo de uma aula, cerca de 50 minutos, e pode se configurar em um tipo de leitura realizável e devidamente mediado.

Será que o conto não poderia oferecer uma possibilidade maior de interlocução sobre o fenômeno literário na sala de aula? Será que por meio desse gênero o professor não teria a possibilidade de acompanhar o desempenho de seus alunos como leitores de literatura em tempo real? Será que o conto não consegue contemplar vários objetivos almejados pela escola para uma educação literária?

\section{Cânone e renovação do cânone}

No seu conhecido texto "Notícia da atual literatura brasileira", publicado em 1873, Machado de Assis constatava que, na literatura brasileira de até então, o conto gozava de fraca tradição e que se tratava de um "gênero difícil, a despeito de sua aparente facilidade, e creio que essa aparência fácil lhe faz mal, afastando-se dele os escritores, e não lhe dando, penso eu, o público toda a atenção de que ele é muitas vezes credor" (ASSIS in AZEVEDO et al. 2013, p. 436).

A observação já denunciava o interesse de Machado pelo conto, lembrando que àquela altura ele já havia publicado os seus Contos fluminenses (1869) e Histórias da meia-noite (1873). No texto de apresentação de Várias histórias, livro publicado em 1895, Machado comparava o conto e o romance: "O tamanho não é o que faz mal a este gênero de histórias, é naturalmente a qualidade; mas há sempre uma qualidade nos contos, que os torna superiores aos grandes romances, se uns e outros são medíocres: é serem curtos" (ASSIS, 2004 , p. 3). O autor intuía, com bastante acerto, que dialogava com diferentes tipos de leitores e que os leitores do jornal e da revista não eram necessariamente os mesmos dos seus romances. Essa preocupação com a recepção de seus textos - o diálogo que travava com um público leitor rarefeito - talvez explique por que sua obra ainda hoje é tão legível.

Sobre o conto, é certo que Machado de Assis elevou o gênero a um nível de elaboração estética que não havia antes em nossa literatura. Desde então, pode-se dizer com certa tranquilidade, que poucos prosadores prestigiados $\mathrm{da}$ 
literatura brasileira não se dedicaram ao gênero. Tal situação permite, com facilidade, abordar os principais romancistas brasileiros que também se dedicaram ao conto (Machado de Assis, Lima Barreto, Guimarães Rosa, Clarice Lispector, Mário de Andrade) e ainda ampliar o cânone escolar com a literatura contemporânea, em que o gênero ocupa um lugar de destaque (Dalton Trevisan, Rubem Fonseca, Caio Fernando Abreu, Moacyr Scliar, João Antônio, Lygia Fagundes Telles, Sérgio Sant'Anna, Daniel Galera, Milton Hatoum). Nesse sentido, seria interessante a escola dispor de antologias de melhores contos brasileiros ou antologias temáticas (amor, trabalho, futebol, preconceito racial, contistas mulheres).

O conto serviria como uma espécie de isca para o aluno, que poderia se interessar pela linguagem de determinado autor e promover leituras por conta própria de outras obras (romances, contos, textos sobre o autor). Isso também impediria que determinados autores fossem tachados de incompreensíveis pelos alunos. Macunaima é, por exemplo, um livro que oferece dificuldades enormes para os alunos do ensino médio. Uma rápida busca na internet prova que se trata de uma leitura vista como difícil pelos jovens leitores, como neste comentário, postado num site de compartilhamento de leituras (Skoob):

Quando li Macunaima pela primeira vez, acho que estava nas mesmas condiçóes de temperatura e pressão (hehe) que muita gente que leu Macunaíma pela primeira (e única) vez. Estudante perto do vestibular, com literatura brasileira enfiada goela abaixo e portanto um leve preconceito sobre algo que não me permitiam conhecer sozinha, no meu tempo. Conclusão? Achei um saco. Só parei de torcer o nariz para o nome de Mário de Andrade depois de conhecer a brilhante coletânea de crônicas chamada Os filhos da Candinha (fica a sugestão aí).

E entấo que eu resolvi dar uma segunda chance e que surpresa ahn. Adorei Macunaima. Devorei o livro nas horas que tinha livre e depois ainda fiquei pensando nele, saboreando alguns momentos e pensando em como deveria ter sido legal conversar com o Mário de Andrade.

(http://www.skoob.com.br/livro/resenhas/1632/maisgostaram). 
O comentário da jovem que se tornou leitora é revelador do abismo entre duas práticas de leitura em choque: a da escola e a dos alunos. A literatura é "enfiada goela abaixo" do estudante, num ambiente de pressão dos exames de avaliação, e tem como resultado final algo previsível: o livro é considerado "um saco". No entanto, ao contrário do que comumente ocorre, essa leitora consegue construir outra imagem do autor a partir do contato com uma antologia de crônicas de Mário de Andrade. Ou seja, é o gênero menor, no sentido de extensão, que lhe permite perceber que talvez não estivesse nas condições "de temperatura e pressão" na primeira vez que teve contato com Macunaima. A releitura do livro se dá de forma antropofágica (devorando, saboreando) e dialógica "como seria legal ter podido conversar com Mário de Andrade".

Ficam algumas questôes: o contato com o gênero "menor" não seria mais proveitoso para esses leitores terem experiências bem-sucedidas de leitura? Não é interessante que uma jovem leitora consiga ter uma visão tão crítica dos motivos que levaram a um contato insatisfatório com determinada obra e que a escola continue insistindo em práticas que levam a isso?

Do ponto de vista didático, o foco nesses gêneros literários menores, que permitem a leitura e a releitura em sala de aula, tem forte potencial de contemplar os objetivos da escola e acrescenta a perspectiva de uma leitura real das obras. Os simulacros de obras teriam sua ação diminuída ou seriam ativados apenas no momento adequado. Abre-se a perspectiva da negociação dos sentidos, de níveis de leitura diferenciados conforme a experiência de cada aluno-leitor, da descoberta de técnicas ficcionais (formas de narrar, construção de personagens, detalhes significativos, relaçóes intertextuais) etc. O professor guia turístico dá lugar ao professor mediador.

\section{Mediação}

Um dos grandes problemas enfrentados pelo professor que indica a leitura de um romance para seus alunos é a impossibilidade que ele mesmo tem de promover uma releitura da obra, por falta de tempo. Isso porque é comum os professores das escolas públicas brasileiras terem cargas horárias de 40 horas. As horas-atividade variam bastante, sendo, normalmente, inferiores à metade das aulas dadas (cerca de 8 a 10 horas). Mesmo considerando que este profes- 
sor possua anotações a respeito do romance em questão, sabe-se que a releitura de uma obra indicada para alunos é o procedimento ideal para que se abra um diálogo produtivo sobre o livro. De um modo geral, o professor acaba recorrendo a textos sobre a obra. Ao perceberem essa prática, os alunos não se sentem suficientemente estimulados para encarar um livro que lhes tomará tempo e que sequer foi relido pelo professor. ${ }^{3}$

Há ainda a prática recorrente de o livro indicado servir unicamente para aplicação de uma prova com questóes de múltipla escolha ou enunciados discursivos esquemáticos demais, remetendo as antigas fichas de leitura. O livro é dispensado e sequer aparece em sua materialidade na sala de aula. Nesse caso, não é raro que os alunos que leram apenas simulacros das obras se saiam bem na referida avaliação. Logo eles descobrem que os livros indicados não precisam ser lidos. Paradoxalmente, a prova é feita para testar quem leu, mas acaba provando que é possível se "dar bem", mesmo não tendo lido a obra.

Propostas com livros que requerem uma leitura fora da escola demandam uma série de estratégias do professor, como aquelas defendidas por Rildo Cosson em Letramento literário - teoria e prática (2012). Tendo atuado como professor da educação básica e na formação de professores de português, Cosson enfatiza a importância de o professor estruturar as discussões em torno dos textos literários nas seguintes etapas: motivação, introdução, leitura, primeira interpretação, contextualização, segunda interpretação e expansão. $\mathrm{Na}$ sequência básica, para o ensino fundamental, as etapas são: motivação, introdução, leitura, interpretaçáo e expansão (COSSON, 2012, p. 75-96). Essa sequência expandida foi desenvolvida como procedimento didático para o ensino médio, visando acrescentar aspectos tidos como importantes pelos professores deste nível de ensino acostumados à historiografia literária. Deve-se destacar que a leitura de obras de maior extensão é acompanhada pelo professor em intervalos preestabelecidos com os alunos.

3 Um pequeno esclarecimento sobre o lugar de onde falo: fui professor da educação básica entre 2000 e 2008. Depois disso, fui professor do curso de Letras da Universidade Federal do Amazonas em Humaitá entre 2008 e 2013. Desde o final de 2013, acompanho alunos de Letras da UFRJ em fase de estágio em escolas públicas do Rio de Janeiro. Dos relatos desses licenciandos, a principal conclusão que tiro é o quase desaparecimento da prática de se indicar livros para leitura na escola brasileira, quando isso acontece é apenas para aplicação de uma prova ou para entrega de um trabalho. A razão disso (na fala dos professores que atuam nas escolas): os jovens não leem. 
Procedimentos semelhantes adotados para um romance podem ser utilizados para abordar um conto. Num dos exemplos da sequência básica, Cosson comenta uma sequência planejada para o conto "No retiro da Figueira", de Moacyr Scliar (COSSON, 2012, p. 67-68). O conto fala sobre um condomínio que oferecia tanta segurança aos seus moradores que eles acabaram se tornando reféns de suas casas (uma situação vivenciada por muitos de nós nas grandes cidades). A atividade de motivação propóe uma moldura criativa, em que os alunos tinham que escolher uma residência em uma cidade para onde supostamente estariam se mudando. A motivação é feita ao longo de uma aula e visa familiarizar os alunos com o tema do texto, ou seja, nesse momento os conhecimentos de mundo do aluno são acionados. Essas molduras criativas podem aparecer tanto na motivação como na fase de expansão, quando os alunos produzem um texto que articule a visão crítica construída ao longo do percurso de leitura.

Em todas as etapas dessas sequências, percebe-se que o papel do professor é o de mediador. Sua função é planejar situaçóes que levem os alunos a falarem sobre o texto e construírem suas interpretaçóes pessoais, que serão ampliadas pelas outras leituras promovidas por seus colegas e pelo professor. Não há uma leitura pronta, dada de bandeja para os alunos, mas leituras que se constroem ao longo do processo. Nesta situação, a função do professor não é a de quem transmite um conhecimento enciclopédico para seus alunos, mas a de quem medeia níveis de leitura que considera desejáveis para aquele grupo. Esse tipo de situação permite que convivam diferentes níveis de leitura num mesmo grupo e que essas diferenças sejam positivas. Essa diferenciação do ensino e da aprendizagem permite a todos desenvolverem competências comunicativas, inclusive o professor, que terá que ajustar a condução das discussões conforme as dificuldades vivenciadas pelos alunos. Ele poderá também ampliar seu repertório de leituras e manter vivo o contato com o texto literário. A insistência na abordagem historiográfica na escola brasileira tem afastado não só os alunos da literatura, mas também os professores, que se tornam leitores de livros didáticos e apostilas.

Outra proposta muito pertinente de mediação foi criada pelo professor, escritor de livros infantojuvenis e teórico da leitura, o inglês Aidan Chambers ${ }^{4}$. Seu livro, Tell Me, publicado pela primeira vez em 1993, tem por princi-

4 Apenas os livros infantojuvenis de Chambers foram traduzidos para o português. Cito aqui uma tradução do Fondo de Cultura Económica que faz parte da coleção "Espacios para Leitura”. Cf.: http://www.aidanchambers.co.uk. 
pal objetivo destacar a importância de as crianças conseguirem falar sobre suas leituras e ouvir as intepretaçóes de seus colegas. Para que isso se dê, o autor propóe um repertório de questôes que permitem ao leitor falar sobre suas leituras. De um modo sintético, o autor comenta o seu método:

Percebemos que, em qualquer grupo de leitura, se os integrantes começam compartilhando suas observaçóes, por mais óbvias que sejam, eles logo acumulam um repertório de entendimento que revela, a todos, o cerne do texto e seu(s) sentido(s). Mesmo quando abordamos ideias bastante complicadas ou abstratas desse modo (por meio de histórias com imagens e de interpretaçôes dialogadas), não sobra quase nada que não seja compreensível até para uma criança pequena. Nessas atividades, há um equilíbrio a ser encontrado entre o respeito pelos direitos do indivíduo como leitor e falante e a leitura construída em conjunto pelo grupo - o texto comunitário, que será sempre mais complexo e revelador do que uma leitura individual. (http://www.aidanchambers.co.uk/readingenviro.htm)

Partilhar o óbvio é o ponto de partida desta proposta. Após a leitura do livro pelos alunos (feita em sala ou em casa), o professor começa fazendo perguntas básicas: o que você gostou, do que você não gostou, o que causou desconcerto / dúvidas e padróes perceptíveis no livro. Nesse momento, as respostas dos alunos são curtas e o professor toma nota delas em quatro colunas. Uma discussão mais aprofundada ocorre após comparar as respostas, tomando como referência aquilo que foi citado mais vezes pelos alunos. Ou seja: um mesmo elemento que causou prazer na leitura para um aluno pode ter gerado dúvidas ou ter aborrecido outros. Esse mesmo elemento pode se constituir num padrão da obra. Como aponta Chambers, a vantagem dessa proposta é que o tema da discussão não é previamente definido pelo professor, mas construído com os alunos durante a discussão sobre o livro.

É evidente que, na condição de mediador, o professor tem questões preparadas para conduzir as discussóes. Nesse ponto, Chambers propóe três tipos de perguntas, a saber: 1) básicas - citadas anteriormente - servem para direcionar o debate; 2) gerais - servem para qualquer livro (Qual foi a primeira 
impressão que teve do livro? Você indicaria esse livro a um colega? etc.); 3) especiais - que se referem às particularidades do livro que está sendo lido. Nesse terceiro grupo, as perguntas procuram direcionar o aluno para aspectos temáticos e literários da obra.

O professor mediador se preocupa com a percepção que os alunos tiveram do texto, se eles foram capazes de entender os mecanismos ficcionais utilizados pelo autor, se eles desenvolveram uma reflexão mais crítica sobre o tema abordado em determinada obra, ou seja, o foco deste professor está na recepção que os alunos têm do texto. Por isso, ele evita indicar uma obra que seja de difícil entendimento ou pelo menos prevê certos problemas de entendimento (criando estratégias para minimizar isso), que determinadas referências (textuais ou não textuais) faltam para que aquela obra seja devidamente compreendida. Esse professor não se assusta quando uma obra de difícil leitura é rejeitada, mas se deixa surpreender quando os alunos conseguem dar conta de uma obra canônica e considerada complicada. Ele entende que dentro de um mesmo grupo há diferentes níveis de compreensão de um texto e que seu objetivo é fazer com que cada aluno aprimore a sua competência leitora, valendo-se das leituras compartilhadas em sala de aula.

Os textos curtos são o lugar ideal para se testar o potencial didático dessas práticas de mediação. O conto oferece a oportunidade de uma práxis da formação de leitores literários. A perspectiva aqui adotada pressupóe que mesmo um leitor com um contato extremamente reduzido com a literatura no ensino básico possa se beneficiar dessas leituras mediadas do conto.

\section{Mediando um conto contemporâneo}

O tamanho do conto tem variado bastante nos últimos séculos. Recentemente, o tempo de uma sentada, típico do leitor do século XIX, foi substituído pelo tempo de uma piada ou de um haicai, como se vê nos microcontos - como os da antologia Os cem menores contos brasileiros do século, organizada por Marcelino Freire (2004). Singular nessa antologia é que ao final dela o leitor é convidado também a escrever, em uma página em branco no final do livro, um microconto com até 50 letras, que passará a fazer parte do livro.

Talvez isso indique uma das características do próprio conto: a participação mais efetiva do leitor, que tem muitas vezes diante de si um texto com 
lacunas, com sugestóes. Muitos contos propóem enigmas ao leitor ou mesmo o enganam. Isso fica mais evidente no microconto, mas também é parte integrante de contos mais longos. Um bom exemplo é o conhecido conto "Apelo", de Dalton Trevisan, usado para ilustrar uma atividade de mediação de leitura. Dada a extensão, o conto está reproduzido na íntegra:

Amanhã faz um mês que a Senhora está longe de casa. Primeiros dias, para dizer a verdade, não senti falta, bom chegar tarde, esquecido na conversa de esquina. Não foi ausência por uma semana: o batom ainda no lenço, o prato na mesa por engano, a imagem de relance no espelho.

Com os dias, Senhora, o leite primeira vez coalhou. A notícia de sua perda veio aos poucos: a pilha de jornais ali no chão, ninguém os guardou debaixo da escada. Toda a casa era um corredor deserto, até o canário ficou mudo. Não dar parte de fraco, ah, Senhora, fui beber com os amigos. Uma hora da noite eles se iam. Ficava só, sem o perdão de sua presença, última luz na varanda, a todas as afliçóes do dia.

Sentia falta da pequena briga pelo sal no tomate - meu jeito de querer bem. Acaso é saudade, Senhora? Às suas violetas, na janela, não lhes poupei água e elas murcham. Não tenho botão na camisa. Calço a meia furada. Que fim levou o saca-rolha? Nenhum de nós sabe, sem a Senhora, conversar com os outros: bocas raivosas mastigando. Venha para casa, Senhora, por favor. (TREVISAN 1979, p. 73)

Essa atividade foi feita em uma aula de prática de ensino para mostrar justamente o papel do professor mediador. A atividade foi pensada para alunos do ensino básico e médio. Um dos objetivos desse tipo de proposta mediada pelo professor é que os alunos interajam com os contos. Cada conto fornece uma entrada interativa diferenciada. No caso deste texto, adotei com alunos do ensino superior a seguinte estratégia. Primeiro, suprimi o título do conto. Em seguida, promovemos a sua leitura. Sem que houvesse qualquer discussão sobre o texto, pedi para que cada aluno atribuísse um título ao conto, que deveria ser formado por uma única palavra-síntese, e 
explicasse o motivo de ter atribuído tal título. Após uns cinco minutos, cada aluno revelava seu título e explicava o motivo da escolha, o que se constituía em uma atividade interpretativa, pois ele tinha que recorrer a elementos do conto para se justificar. Os títulos eram anotados no quadro. A maior recorrência foi da palavra saudade, mas houve também: ausência, separação, tristeza, vazio.

Com a revelação do título, abriu-se espaço para uma análise mais estilística do texto, percebendo o tempo transcorrido (um mês longe de casa), o papel desta mulher na casa (sua ausência se manifesta para o marido pela falta de alguém para fazer os serviços domésticos), a presença dos filhos (que aparecem por meio de uma metonímia: "bocas raivosas mastigando").

Tudo isso aponta para um fato: o enredo do conto é praticamente inexistente, resumindo-se a: um marido que pede para a esposa voltar para casa. É um acontecimento banal que se reveste de lirismo: a mancha no lenço, o vulto que é pressentido no espelho, as violetas que murcham, o canário que se cala. Nesse momento, o professor poderia fazer comentários sobre a obra, ressaltando como é recorrente nos contos de Dalton Trevisan essa temática (as eternas brigas entre João e Maria).

Importante é não tratar o conto de uma forma pasteurizada/padronizada. A palavra cachorro serve para designar tanto um chiuaua como um são-bernardo e eles são muito diferentes entre si (como se fossem duas criaturas distintas). A palavra conto também comporta seres muito distintos entre si, podendo se referir a contos de fadas ou a contos populares, que necessitam de um tratamento didático diferenciado. Já o conto literário, que não está ligado à tradição oral, mas à tradição impressa, também apresenta vários matizes, conforme a época ou o autor que o praticou. O ditado "quem conta um conto aumenta um ponto" vale para o conto popular, em que as histórias são recontadas e alteradas conforme a situação de interlocução e ao sabor da imaginação de quem conta. Isso não vale para contos ligados à tradição impressa, em que situaçóes narrativas mais elaboradas são criadas tendo em vista as possibilidades oferecidas pelo suporte (jornal, revista, livro) e o tipo de leitor para o qual o texto se destina.

Um conto de Machado pode dar uma pequena amostra desta diferença de tratamento de autor para autor e de período para período. 


\section{Mediando Machado}

Os primeiros contos de Machado foram publicados entre 1864 e 1869 no Jornal das Familias e reunidos depois no volume Contos fuminenses (1869). Essas primeiras narrativas são relativamente longas, prevalecendo nelas a trama sobre as observaçôes de cunho psicológico. Como observa Marta de Senna: "Longe estamos da narrativa lacunar de romances e contos posteriores. Aqui, tudo (ou quase) é dito, tudo (ou quase) é explicado" (SENNA, 2007, p. XXI).

O salto machadiano no conto parece estar ligado à admiração do autor brasileiro por Edgar Allan Poe, que tinha desenvolvido importantes teorias sobre o conto. Poe pregava que todos os elementos do conto deveriam convergir para o fim, surpreendendo o leitor. Para alcançar esse efeito, era comum a adoção da técnica das duas histórias, como comenta Ricardo Piglia: "Um relato visível esconde um relato secreto, narrado de um modo elíptico e fragmentário. $\mathrm{O}$ efeito de surpresa se produz quando o final da história secreta aparece na superfície" (PIGLIA, 2004, p. 89-90).

A história secreta faz o leitor perceber que o narrador semeou aqui e ali pistas que passaram batidas em uma primeira leitura. A releitura coloca o leitor na posição de um investigador que retoma a cena do crime para rever os indícios que não foram considerados num primeiro momento. Essa técnica encontra-se em contos como "A causa secreta" e "A cartomante".

Note-se que Machado se vale ainda de outras técnicas ficcionais, por exemplo, contos em que quase nada acontece, como "Missa do galo". Outros apresentam temáticas recorrentes ou têm o foco na construçáo de personagens risíveis pelas situaçóes paradoxais que vivenciam, como Rangel de "O diplomático" ou Pestana de "Um homem célebre”. Há ainda o Machado que constrói fábulas morais modernas, como "A igreja do diabo", "Teoria do medalhão" e "Um apólogo".

Desse modo, é equivocado tratar o conto como um gênero com características fixas, pois um mesmo autor se vale de técnicas muito distintas entre si. Cabe ao professor mediador ter ciência disso e preparar atividades que redimensionem as técnicas usadas pelo autor, fazendo com que os alunos as vejam em uso. 
O conto "A carteira", publicado na revista $A$ Estaçãos, é um exemplo das duas histórias contadas paralelamente com o nítido propósito de enganar o leitor. A trama é simples: passando pela Rua do Ouvidor, o advogado Honório encontra uma carteira recheada de dinheiro. O narrador retoma em flashback os acontecimentos que tornam aquele fato importante: Honório está endividado por conta dos gastos excessivos da esposa (festas, carruagens, vestidos). É construído um conflito de consciência: devolver a carteira ou não. A solução: caso haja alguma identificação, a carteira deve ser entregue ao dono. Honório abre a carteira e descobre que ela é do seu melhor amigo e frequentador assíduo de sua casa, Gustavo. Arrasado, Honório retorna para casa, onde encontra a esposa, Amélia, e Gustavo. Devolve a carteira e deixa o amigo e a esposa sozinhos. Ao sair de cena, Amélia toma a carteira de Gustavo, retira uns papeizinhos que havia nela (bilhetes de amor trocado entre os amantes) e rasga-os. Nesse momento, é revelada a segunda história: Honório era traído pela mulher e pelo melhor amigo.

Assim como o marido traído, o leitor também foi enganado, sendo levado a acreditar que o conflito da história se resumia à devolução da carteira e às dívidas de Honório. A releitura do texto permite averiguar que várias pistas tinham sido semeadas pelo narrador, indicando o triângulo amoroso. Desse ponto de vista, algumas frases ganham novo sentido: "agradar à mulher, que vivia aborrecida da solidão", "Quando o Gustavo, que ia todas as noites à casa dele", "D. Amélia tocava muito bem ao piano, e que o Gustavo escutava com indizível prazer".

Agora fica a questão: como fazer com que os alunos percebam essa estruturação do conto? O melhor caminho seria enganá-los também, conduzindo o olhar deles para o conflito moral. A leitura de uma matéria de jornal falando sobre alguém que achou uma grande soma e resolveu devolvê-la seria uma boa solução. Há vários relatos desse gênero, envolvendo pessoas que, apesar de serem muito pobres, resolvem devolver o dinheiro encontrado. Essa atividade de motivação despertaria a atenção deles. Em seguida, a leitura do conto, que deve ser feita pelo professor para que a surpresa final seja sentida pelos alunos (uma leitura equivocada poderia dispersar a atenção da sala). Terminada

5 O conto teria sido publicado em 15 mar. 1884, na revista $A$ Estação. Essa informação consta da edição da Nova Aguilar, porém em consulta ao acervo digital desta revista, no site da Biblioteca Nacional, não pude confirmar essa informação. 
a leitura, os alunos comentam as impressóes que tiveram sobre o texto. Em seguida, devem identificar as frases que ganham novo sentido com a releitura.

No plano motivacional, esse conto pode servir como um convite à leitura de outros contos do autor, selecionados pelo professor. Nessa seleção, devem ser incluídos contos que tenham essa estrutura de duas histórias e outros que se valham de técnicas diferenciadas. A leitura de um número razoável de contos pode habilitar os alunos para um desafio maior: um romance de $\mathrm{Ma}$ chado de Assis. Esse é um objetivo possível, que deve ser almejado pela escola. Agora, se a proposta for unicamente adotar o livro para a realização de uma prova, é mais honesto o professor deixar esse objetivo claro, indicar sites para pesquisa, fornecer textos de apoio (críticas, resenhas, comentários) e dizer: "vocês também podem ler o livro". Afinal, esse tipo de leitura - de textos que falam sobre outros textos - existe. A única questão é sua adoção como substituto da experiência literária.

\section{Para finalizar}

A historiografia é uma bananeira que já deu cacho (minguado, aliás). Ela teve seu nascimento na tradição escolar brasileira no século XIX. Foi uma forma de dar um estatuto científico para o estudo da literatura na escola, substituindo os estudos de cunho retórico e estilístico então em voga. Tal abordagem se perpetuou por conta de sua ampla divulgação em materiais didáticos, por sua adoção em currículos, pela prática dos professores de língua e literatura no ensino médio e pela eventual cobrança desses conteúdos em exames de admissão para universidades (CEREJA, 2005). Como se vê, trata-se de um modo de ensino fundamentado em uma larga tradição. Uma tradição de ensino transmissivo, enciclopédico e que não contribui para a formação de leitores.

Esse modelo de ensino já não fazia sentido há cinquenta anos e hoje, com todo o acesso a informaçóes enciclopédicas que nossos alunos têm, ele se mostra ainda mais sem sentido. Os próprios documentos oficiais questionam esse modelo, em que o texto literário acaba sendo substituído por seus simulacros, e mesmo os exames de avaliação não têm mais seu foco na historiografia literária. A maior parte das questóes do Enem de literatura mede a capacidade leitora do aluno (LUFT \& FISCHER, 2015). 
Parece-me que a distorção aqui é semelhante àquela que ocorre nas aulas de língua portuguesa quando o professor dá uma ênfase maior à nomenclatura gramatical normativa e deixa de lado a análise de questóes de uso da norma padrão na escrita e na oralidade. Os conhecimentos da gramática normativa, com todas as suas contradiçôes entre os gramáticos, são necessários ao professor. Enfiar esse tipo de informação goela abaixo dos alunos, como tem acontecido, é inútil, improdutivo e contraindicado pelos documentos oficiais. Resultado dessas distorções: a maioria dos alunos sai da escola com a certeza de que não sabem português, depois de terem passado mais de uma década pelos bancos escolares. Por sua vez, a ênfase historiográfica inviabiliza a leitura real de obras que contribuiriam para a formação de cidadãos críticos e de leitores competentes, do mundo e da palavra.

\section{Referências}

ASSIS, Machado de. Várias histórias. São Paulo: Martins Fontes, 2004.

A carteira. http://www.literaturabrasileira.ufsc.br/documentos/ ?action $=$ download $\&$ id $=8219,08 / 10 / 2015$.

. Notícia da atual literatura brasileira - Instinto de nacionalidade. In: CALLIPO, Daniela Mantarro; AZEVEDO, Sílvia Maria; DUSILEK, Adriana (Org.). Machado de Assis: crítica literária e textos diversos. São Paulo: Unesp, 2013. p. 429-441.

BAUMAN, Zygmunt. "Há uma crise de atenção" - Para pensador polonês Zygmunt Bauman, internet dificulta a lida diária com a realidade. O Globo, Sociedade, p. 41, 13/09/2015.

CEREJA, Willian Roberto. Ensino de literatura - uma proposta dialógica para o trabalho com literatura. São Paulo: Saraiva; Atual, 2005.

CHAMBERS, Aidan. Dime - los niños, la lectura y la conversación. Trad. Ana Tamarit Amieva. México: FCE, 2007.

. Tell Me with The Reading Environment, http://www.aidanchambers. co.uk/readingenviro.htm, 03/10/2015.

COMPAGNON, Antoine. O demônio da teoria - Literatura e senso comum. Trad. Cleonice Paes Barreto Mourão e Consuelo Fortes Santiago. 2. ed. Belo Horizonte: UFMG, 2010.

COSSON, Rildo. letramento literário - Teoria e prática. São Paulo: Contexto, 2012. FREIRE, Marcelino (Org.). Os cem menores contos brasileiros do século. Cotia (SP): Ateliê Editorial, 2004. 
HOUDART-MÉROT, Violaine. Da crítica da admiração à leitura do "scriptível”. In: LUFT, Gabriela Fernanda Cé; FISCHER, Luís Augusto. Literatura, leitura e ensino - a Enem e os impactos das leituras obrigatórias dos exames vestibulares para formação de leitores. Contexto - Revista do Programa de Pós-gradução em Letras, 27, Vitória (ES), 2015, http://www.periodicos.ufes.br/ contexto/article/view/10418, 10/10/2015.

PIGLIA, Ricardo. Formas breves. Trad. José Marcos Mariani de Macedo. São Paulo: Companhia das Letras, 2004.

ROUXEL, Annie; LANGLADE; Gérard; REZENDE, Neide Luzia (Org.). Leitura subjetiva e ensino da literatura. Sáo Paulo: Alameda, 2013.

SODRÉ, Muniz. Tecnologia e diversidade. In: Reinventando a educação - diversidade, descolonização e redes. 2 ed. Petrópolis (RJ): Vozes, 2012.

TREVISAN, Dalton. Mistérios de Curitiba. Rio de Janeiro: Record, 1979, p. 73.

Apelo. Acesso em http://www.releituras.com/daltontrevisan_apelo. asp, 03/10/2015.

\title{
READING MEDIATION OF THE SHORT STORY IN THE CLASSROOM
}

\begin{abstract}
In Brazilian high school, literature is often taught as if it was encyclopedic knowledge and through the reading of commentaries and criticisms of actual literary works. This paper questions these practices and offers an alternative approach in which the teacher becomes the mediator of readings, directing its focus to the reception of texts by the students. In order to exemplify this proposal, this paper draws on the use of short stories as learning practice in the classroom.

KEY-WORDS: Reading mediation; the short story in the classroom; literature teaching and learning.
\end{abstract}

Recebido em: 13/03/2015

Aprovado em: 20/01/2016 